\title{
THE APPLICATION OF TECHNOLOGY ACCEPTANCE MODEL ON INTERNET BANKING USERS IN THE CITY OF DENPASAR
}

\author{
Ni Nyoman Kerti Yasa ${ }^{1}$ \\ Luh Putu Rara Ayu Ratnaningrum ${ }^{2}$ \\ Putu Gde Sukaatmadja ${ }^{3}$ \\ 1,3 Economics and Business Faculty of Udayana University \\ Jl. P. B. Sudirman Denpasar, Bali 80232 \\ Email: manraikerti@yahoo.co.id \\ ${ }^{2}$ Master Program in Management of Udayana University \\ Jl. P. B. Sudirman Denpasar, Bali 80232
}

\begin{abstract}
The analysis unit of this study was clients of the five major banks in Denpasar. This study aimed to analyze the implementation of internet banking using Technology Acceptance Model (TAM) approach. The research method was SEM which was processed by using SPSS dan AMOS. The results of this study showed that both perceived ease of use and perceived usefulness had significant and positive effects on the attitude towards using internet banking. Both perceived ease of use and perceived usefulness also had positive and significant effects on actual usage. Attitude toward using had a significant and positive relationship with actual usage.
\end{abstract}

Keywords: Internet Banking, TAM, Perceived Ease of Use, Perceived Usefulness, Attitude toward Using, Actual Usage

\begin{abstract}
Abstrak
Unit analisis dari penelitian ini adalah nasabah dari lima bank besar di Denpasar. Penelitian ini bertujuan untuk menganalisis implementasi internet banking dengan pendekatan Technology Acceptance Model (TAM). Penelitian ini menggunakan metode kuesioner dengan metode analisis deskriptif dan analisis statistik. Data diproses dan dianalisis dengan Structural Equation Model (SEM) menggunakan SPSS dan AMOS. Hasil dari penelitian ini, variabel perceived ease of use dan perceived usefulness memiliki hubungan positif dan signifikan secara langsung tehadap attitude toward using. Perceived ease of use dan perceived usefulness juga memiliki pengaruh positif dan signifikan secara langsung terhadap actual usage. Attitude toward using memiliki hubungan positif dan signifikan secara langsung terhadap actual usage.
\end{abstract}

Kata Kunci: Internet Banking, Technology Acceptance Model (TAM), Perceived Ease of Use, Perceived Usefulness, Attitude Toward Using, Actual Usage

\section{INTRODUCTION}

The rapid development of internet has changed the way companies relate to their clients, including banking business (Jun \& Cai, 2001). Since internet is still largely used as a shopping media, banking service providers have to predict the acceptance of internet by clients and understand why the usage of this media still prevails now (Manzano et al., 2009). Clients prefer the service through internet because they do not have to meet vendor or seller personally and to endure the behaviors of other clients (Walker \& Johnson, 2006; Mitic \& Kapuolas, 2012).
The principal change the banking industry because of the internet was the transformation from traditional banking to electronic banking (Yahyapour, 2008). Internet banking could be defined as a design on the web page by a bank to give information of the bank's products and services, which in further stage would involve provision of facilities to access accounts, transfer funds and buy finance products, or to use online services, which was called online banking transaction (Sathye, 1999). Internet banking was also a form of bank service based on information technology which could be utilized to raise clients' satisfaction and loyalty (Anggraeni \& Kerti Yasa, 2012). 
Internet banking helped banks to reduce transaction cost, improve bank image in the market, and improve bank's responses towards the demands of the market (Kerem, 2003). Clients' awareness and response to use internet banking was the key factor for a bank to provide internet banking service (Cheung, 2001; Juwaheer et al., 2012; Giovanis et al., 2012). The phenomena of the behaviors of e-banking users has been studied by Jaruwa-chirathanakul \& Fink (2005), Zhao et al. (2010), and Kesharwani \& Bisht (2012).

Kaleem \& Ahmad (2008) stated that e-banking was a means to minimalize discomfort, reduce transaction cost and safe time. The ease in obtaining information and the many benefits provided had increased the utilization of information system (Rigopoulos \& Askounis, 2007; Islam \& Chick, 2011; Lech, 2012; Choi et al., 2011). Banks did not have to open branch offices, could save operational costs and fixed costs by exchanging employees' function and physical facilities with information technology (Jun \& Cai, 2001; Rahardjo, 2001; Zhao et al., 2008; Laukkanen et al., 2008; Manzano et al., 2009).

Internet banking had fulfilled the requirements that should be met by a technology in order to be adopted: first, the services provided should be supportive; and second, the services could be accessed and offered relevant market, had supportive benefits and could be easily obtained (Walker \& Johnson, 2006). The utilization of information technology by banks (internet banking) and its benefits are still of chief interest in researches. Although there are significant advancements in hardware and software, the problem that is yet to be overcome is the low usage of the information system, which is proved by the imbalance between the number of internet banking users and the number of banks' clients in Indonesia.

Technology Acceptance Model (TAM) offered a strong and simple explanation of the acceptance of technology and the behavior of the technology users (Davis, 1989). Technology Acceptance Model (TAM) was a model that was designed to predict acceptance of computers and factors relating to it (Widyarini, 2005). Davis (1993) defined Technology Acceptance Model (TAM) as a model established to analyze and under-stand the factors that influence the acceptance of the utilization of computer technology. TAM aimed to explain and estimate the factors that influenced the acceptance of users to a technology in an organization. TAM explained the cause and effect relationship between conviction and behavior, purpose or need and the actual usage by users of an information system.

According to Davis (1989), there were two chief concepts in users' acceptance, namely perceived ease of use and perceived usefulness. Perceived ease of use was defined as the degree of a person's conviction that the usage of an information system technology was easy and did not demand hard effort. Perceived usefulness was defined as the degree of a person's conviction that the usage of an information system technology could raise performance. The usage of internet banking was determined by a person's perception and attitude which would form the person's behavior in using an information technology (internet banking).

This study was a replication of a previous study carried out by Davis (1993). Both perceived ease of use and perceived usefulness had influence on attitude toward using which would influence actual usage. Attitude toward using in TAM was defined as attitude toward a system usage in the form of acceptance or refusal when a person uses a technology in his tasks (Davis, 1993). Davis (1989) defined actual system usage as a form of external psychomotoric response which was measured by a person through real usage. The user would use a technology if he or she believed that the technology was beneficial and easy to use, and he or she would use the technology continuously. Perceived ease of use and perceived usefulness directly influenced actual usage without the interference of attitude toward using, and this study aimed to prove the influence of ease of use and usefulness on attitude, and then on actual usage of internet banking. Based on the discussion above, this study aimed to find out and add references of the influence of perceived ease of use and perceived usefulness on attitude toward using and on actual usage of internet banking.

\section{THEORETICAL BASE AND HYPOTHESES}

Theoretically, this study was derived from the concept of clients' behavior, namely the study on how people made decisions to use available resources (time, money, effort) to buy consumer goods (Schiffman \& Kanuk, 2008). Empirically, the previous studies on the adoption behavior of online services resulted in various formulations. One study that could be made was adopting and combining the theoretical concept of clients' behaviors with the Technology Acceptance Model (TAM) in the context of internet banking.

Kusuma \& Susilowati (2007) stated that internet banking was a form of electronic banking offered through internet where clients could make financial transactions or use financial services in a virtual environment. Technology Acceptance Model (TAM) was a popular and extensively used model in studies on information technology adoption process, including internet banking. The simplicity and the ability to explain the cause and effect relationship became the chief reasons of using TAM (Davis, 1989). TAM proposed that two individual convictions, namely 
perceived usefulness and perceived ease of use were the main determinants in adoption behavior (attitude toward using).

Perceived ease of use of a technology is a person's conviction that the computer is easy to understand and to use, while perceived usefulness is a person's conviction that the usage of a technology will benefit the user. In TAM, attitude toward using is defined as attitude toward the usage of system in the form of acceptance or refusal when a person uses a technology in his tasks. Actual usage is the actual adoption of a technology, which can be seen in the measurement of the frequency and time length of the usage of the technology.

Chau \& Lai (2003) proposed that the ease of use in internet banking had a relationship with ability and willingness. Davis (1989) proposed that besides ease, benefit was also a factor which influence the acceptance of a system. Consequently, the attitude to use would be established, in which clients were motivated to spend their time to carry out their banking activities through internet banking. Clients' attitude toward adoption or clients' acceptance to a new information system had serious implications on the success of the new system. If clients refused to accept or adopt the new system, the system would not bring maximum benefit for the banks. While clients who accepted the new system would be willing to perform changes and to give time and effort to start using the new system.

\section{Conceptual Frame}

In accordance with previous discussion, TAM was formed by two individual convictions, namely perceived ease of use and perceived usefulness which constituted the chief source of the concept of this study. Perceived ease of use and perceived usefulness were indicated to have influence on attitude toward using in the usage of internet banking. Then attitude toward using would directly influence actual usage. Perceived ease of use and perceived usefulness were also indicated as having direct influence on actual usage without the interference of attitude toward using. The conceptual frame of this study was shown in Figure 1.

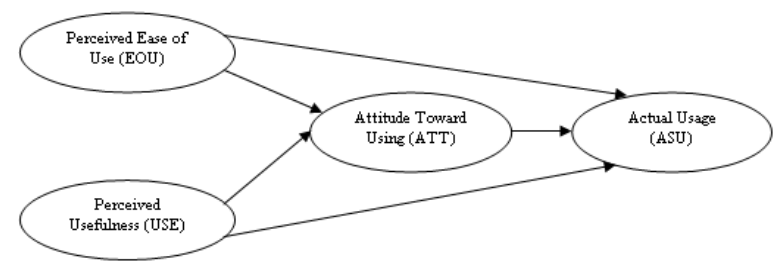

Figure 1. Concept of the Study on the Relationships between Perceived Ease of Use, Perceived Usefulness, Attitude Toward Using, and Actual Usage of Internet Banking

\section{Hypotheses of the Study}

As has been stated previously, this study used Technology Acceptance Model (TAM) as its basis. From the model in Figure 1, we developed the following hypotheses:

\section{The Influence of Perceived Ease of Use on At- titude Toward Using Internet Banking}

Davis (1993), Chau \& Lai (2003), Kusuma \& Susilowati (2007), Medyawati et al. (2011), and Jahangir \& Begum (2008) found in their studies that perceived ease of use had a positive and significant relationship with attitude toward internet banking. Davis $(1989,1993)$ defined ease of use as the degree of a person's conviction that the computer could be understood easily. The ease of use in internet banking would motivate clients to explore its features and detailed system functions (Kusuma \& Susilowati, 2007). Thus, favorable attitude of clients toward internet banking would be established and clients would be willing to spend much time to navigate in banking cyber world to perform their banking activities. Medyawati et al. (2011) stated that ease of use in internet banking attracted clients to use the technology more often. The ease of use enjoyed by clients while applying internet banking would bring many benefits to clients. The hypothesis that we would test was:

$\boldsymbol{H}_{\boldsymbol{l}}$ : Perceived ease of use had a positive and significant influence on attitude toward using internet banking

\section{The Influence of Perceived Usefulness on Attitude Toward Using Internet Banking}

In their studies, Chau \& Lai (2003) and Widyarini (2005) found that usefulness had a positive and significant influence on attitude toward using internet banking. Davis (1989) defined usefulness as the degree of a person's conviction that the use of a technology would improve his or her performance. The measurement of the usefulness was based on the frequency of usage and the variety of the applications applied. Jahangir \& Begum (2008) found in their study that there was a positive and significant relationship between usefulness and attitude toward using internet banking. The studies of Davis (1993) and Yahyapour (2008) also found that usefulness had a positive and significant relationship with attitude of using internet banking. A person's positive attitude toward internet media would urge the person to optimize the effectiveness or usage of internet (Widya- 
rini, 2005). Chau \& Lai (2003) revealed the importance of providing useful services for clients by internet banking. Financial institutions need formulations of strategies which will create positive perceptions of the usefulness of the services of internet banking, which in turn will positively influence users to adopt the technology. The usefulness of internet banking is a usefulness obtained or expected by clients to help carrying out their tasks and works, therefore the usefulness of internet banking influence clients' attitude toward the system. The hypothesis that we would test was:

$\boldsymbol{H}_{2}$ : Perceived usefulness had a positive and significant influence on attitude toward using internet banking.

\section{The Influence of Perceived Ease of Use on Actual Usage of Internet Banking}

The positive and significant relationship between perceived ease of use and actual usage was proved by the studies of Davis (1989), Eriksson et al. (2005), Yusoff et al. (2009), Rigopoulos \& Askounis (2007), and Manzano et al. (2009). In his study, Sathye (1999) found that $40 \%$ individual respondents and $48 \%$ company respondents mastered the use of internet, but did not use internet banking because they considered it was difficult to apply internet banking. In other words, ease of use influence the use of internet banking. Yusoff et al. (2009) in a study on the use of e-library stated that when students considered e-library easy to use, they preferred to use the technology to find the information they need to improve the quality of their assignments. The hypothesis we would test was:

$\boldsymbol{H}_{3}$ : Perceived ease of use had a positive and significant influence on actual usage of internet banking.

\section{The Influence of Perceived Usefulness on Actual Usage of Internet Banking}

The positive and significant relationship between perceived usefulness and actual usage was proved by the studies of Davis (1989) and Rigopoulos \& Askounis (2007). While the study of Yusoff et al. (2009) on the usage of e-library found that when students considered that the technology was useful, the usage of e-library would increase. The usage of a technology implied the conviction that the method of presenting information by the technology was useful and became an alternative choice (Walker \& Johnson, 2006). The hypothesis that we would test was:

$\boldsymbol{H}_{4}$ : Perceived usefulness had a positive and significant influence on actual use of internet banking.

\section{The Influence of Attitude Toward Using on Actual Usage of Internet Banking}

Clients' attitude or willingness to use the service of e-banking would cause e-banking to be accepted and intensively used by clients (Medyawati et al., 2011). Ndubisi \& Sinti (2006) stated that clients' attitude and the features of internet banking caused internet banking to be accepted by bank clients in Malaysia. The positive relationship between attitude toward using and actual usage was found in the studies of Davis (1993) and Medyawati et al. (2011). The hypothesis that we would test was:

$\boldsymbol{H}_{5}$ : Attitude toward using had a positive and significant influence on actual usage of internet banking.

\section{RESEARCH METHOD}

The location of research was the city of Denpasar. Suiting the respondents' situation, where the head offices and main branches of all public banks in the province of Bali were concentrated in Denpasar, this study was carried out in that city. The subjects of this study were the clients of public banks in the working area of Indonesia Bank Office in Denpasar which offered internet banking facilities, and the object of this study was the behavior of internet banking users, namely perceived ease of use and perceived usefulness which was related to attitude toward using and actual usage of internet banking.

The data for this study was obtained through surveys by questionnaires, which was done by sending via email a set of questions and written statements to be answered by respondents. The instrument used in this study was questionnaires which contained closed statements, where questions or statements were presented together with interval scale. Interval scale was a numeric scale to rank object in such a way so that the numeric distance represented the distance of the characteristics being measured (Malhotra, 2006).

\section{Population and Sample}

The population of this study was unlimited, the number and characteristics of the respondents were not definitely known. The sampling technique employed was purposive sampling with the following criteria: (1) Respondents were clients of one of the five banks that had been selected, (2) Respondents had access to the internet banking of one of the five banks that had been selected, and (3) Respondents made transactions through internet banking minimally 
twice in a month; which was then combined with non probability sampling, with consideration to unlimited number of population of unknown characteristics (Malhotra, 2006). The respondents were all the clients which had access to and had made transactions through internet banking in public banks in Denpasar which provided internet banking services. In this study, respondents were taken from five public banks which provided internet banking.

Ferdinand (2002) stated that the sampling measurement number should be 5-10 times the number of parameters being estimated. Therefore the samples taken for this study were 115 respondents ( 23 indicators $x$ 5). However, in data collecting process, five questionnaires were rejected because the respondents did not answer the questions completely, so the questionnaires whose data was valid to be processed were 110 questionnaires.

\section{Research variables and their measurements}

Perceived ease of use was measured by six indicators developed from the studies of Davis (1989), Gefen et al. (2003), Rigopoulos \& Askounis (2007) and Yahyapour (2008), with 0.914 reliability. Perceived usefulness was measured by six indicators developed from the studies of Davis (1989), Rigopoulos \& Askounis (2007), and Yahyapour (2008) with 0.911 reliability. Attitude toward using was measured by five indicators developed from the studies of Kusuma \& Susilowati (2007) and Yahyapour (2008) with 0.928 reliability. Actual usage was measured by six indicators developed from the studies of Eriksson et al. (2005), Rigopoulos \& Askounis (2007), and Yusoff et al. (2009) with 0.833 reliability.

\section{Analysis Tools}

Before the data was processed and analyzed, we made a test of the data quality to know the sincerity of the respondents in answering the questionnaire questions. The tests were validity test and reliability test which were performed in a computer using the SPSS program for Windows Release. Validity test was a tool which tested how accurate and precise a measurement tool carried out its measuring function (Sugiyono, 2008). Validity test aimed to examine the accuracy of the questionnaire questions in measuring data, and to know the respondents' understanding of the questionnaire questions which was indicated by the small percentage of respondents who answered differently from other respondents. Sugiyono (2008) stated that measured variables were valid if the factor loading $(r) \geq 0.3$ (for $n=30$, at $\alpha=5 \%$ ).
Sugiyono (2008) stated that reliability was an index number which showed the consistency of a measurement tool in measuring similar phenomena. Reliability test aimed to find out how great the concentration of the measurement tool was, so that when the measurement tool was used again to test similar object with similar technique in another time, the result would be the same. Reliability test showed how far a measurement tool could be relied upon. The reliability test in this study used the analysis technique with Alpha Cronbach formula with the aid of computer. A measurement tool was considered reliable if the Alpha Cronbach value was $\geq 0.6$.

The analysis of measurement model employed in this study was confirmatory factor analysis which was meant to confirm all the indicators that formed each construct. The data analysis technique employed in this study used Structural Equation Modeling with AMOS program.

\section{RESEARCH RESULT AND DISCUSSION}

\section{Respondents' Characteristics}

Results of the analyses showed that the majority of the respondents had used internet banking for more than 12 to 24 months. BCA was the most often used by respondents in internet banking transactions (46.36\%), followed by Bank Mandiri (33.6\%), BNI (13.63\%), CIMB Niaga (5.45\%) and lastly OCBC NISP $(0.90 \%)$. Sampling was taken from those five banks in regard to clients' enthusiasme in using internet banking.

The comparison between male and female respondents was $63.63 \%$ to $36.36 \%$. Regarding age, the respondents who used internet banking most actively were clients between 21-30 years of age, while in regard of education, respondents with university education were $63.63 \%$, and the others were respondents with post graduate education (20.90\%), Senior High School education (8.18\%), and Academy or Diploma Program education (7.27\%). In regard of income, respondents with the income of $\leq$ Rp5,000,000,- were the most active ones in using internet banking.

\section{The Result of Model Feasibility Test}

The entire model feasibility test was performed by using SEM (Structure Equation Modeling), which was also used to analyse the proposed hypotheses. The result of the test was as shown in Figure 2. 


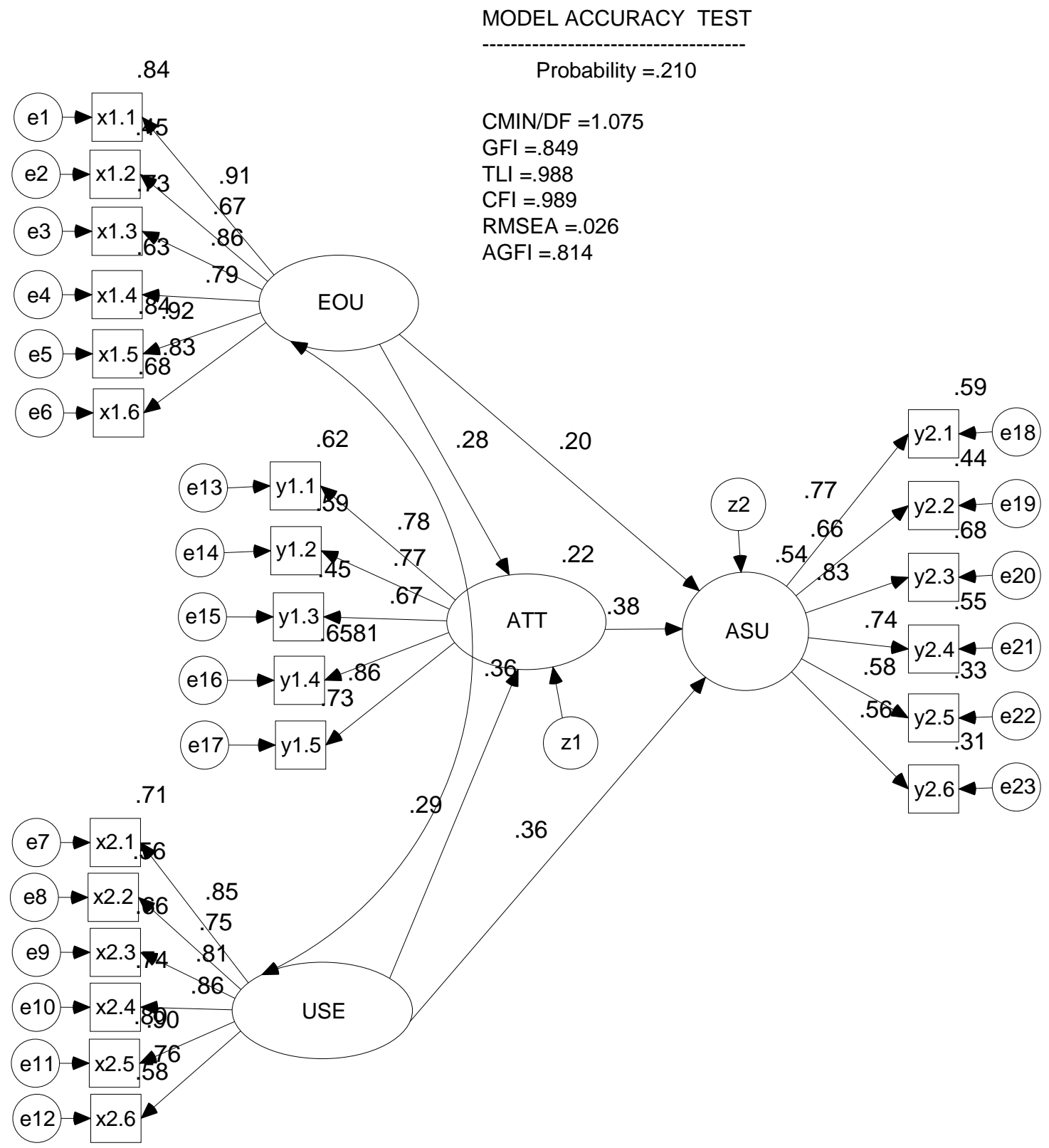

Figure 2. The Structural Equation Model of the Application of Technology Acceptance Model (TAM) on The Users of Internet Banking in the City of Denpasar

Table 1. SEM Test Result of Goodness of Fit Model

\begin{tabular}{lccc}
\hline \multicolumn{1}{c}{ Goodness of Fit Measure } & Cut-off Value & Analysis Result & Model Evaluation \\
\hline In Chi-square & Expected to be small & 240.793 & Good \\
Probability & $\geq 0.05$ & 0.210 & Good \\
RMSEA & $\leq 0.08$ & 0.026 & Good \\
GFI & $\geq 0.90$ & 0.849 & Marginal \\
AGFI & $\geq 0.90$ & 0.814 & Marginal \\
CMIN/DF & $\leq 2.00$ & 1.075 & Good \\
TLI atau NNFI & $\geq 0.95$ & 0.988 & Good \\
CFI & $\geq 0.95$ & 0.989 & Good \\
\hline
\end{tabular}

From the data processing we found that all the constructs used in making the research model had fulfilled the requirements of goodness of fit. Thus, the model fitted the sample data. The test result of the value of factor loading for each indicator could be seen in Table 1. 
Table 2. Estimation of Regression Weights of the Analysis Model of the Application of TAM on the Users of Internet Banking in the City of Denpasar

\begin{tabular}{cccc}
\hline & Estimate Standardize & S.E. & $\boldsymbol{P}$ \\
\hline ATT <--- EOU & 0.276 & 0.086 & 0.008 \\
ATT <--- USE & 0.290 & 0.108 & 0.006 \\
ASU <--- ATT & 0.384 & 0.099 & $* * *$ \\
ASU <-- EOU & 0.200 & 0.073 & 0.030 \\
ASU <--- USE & 0.364 & 0.099 & $* * *$ \\
\hline
\end{tabular}

Table 1 showed that all the constructs used to make the research model in the analysis process of confirmatory factor, Chi-Square, Probability, RMSEA, GFI, AGFI, CMIN/DF, TLI, CFI had fulfilled the goodness of fit criteria. GFI and $A G F I$ were under the cut-off value, but still in the tolerance limit, which was usually called marginal, thus the model could be considered fit.

\section{Hypotheses Tests}

The hypotheses tests of the analyses of Technology Acceptance Model (TAM) on the users of internet banking services in the city of Denpasar were performed by observing the $(p) 0.05$ probability of the estimation result of regression weights of structural equation model using multigroup analysis method.

From the output of the estimation of Regression Weights in Table 2 we could perform the hypotheses tests of this study, as follows:

1) Hypothesis 1 which stated that perceived ease of use had a positive and significant influence on attitude toward using internet banking could be accepted with a probability of $0.008(<0.05)$ and a coefficient value of 0.276 .

2) Hypothesis 2 which proposed that perceived usefulness had a positive and significant influence on attitude toward using internet banking could be accepted with a probability of $0.006(<0.05)$ and a coefficient value of 0.290 .

3) Hypothesis 3 which suggested that perceived ease of use had a positive and significant influence on actual usage of internet banking could be accepted with a probability of $0.030(<0.05)$ and a coefficient value of 0.200 .

4) Hypothesis 4 which stated that perceived usefulness had a positive and significant influence on actual usage of internet banking could be accepted with a probability of $0.000(<0.05)$ and a coefficient value of 0.364 .

5) Hypothesis 5 which proposed that attitude toward using had a positive and significant influence on actual usage of internet banking could be accepted with a probability of $0.000(<0.05)$ and a coefficient value of 0.384 .

\section{Discussion of the Results of the Study}

\section{The Influence of Perceived Ease of Use on Attitude Toward Using Internet Banking}

The result of the hypotheses tests showed that perceived ease of use had a positive and significant influence on attitude toward using internet banking. The formation of respondents' attitude to continue using internet banking depended on the ease provided by internet banking which caused respondents to consider that internet banking made his banking tasks lighter.

This indicated that the internet banking technology adopted by the banks in order to give better services to clients had been presented by the banks successfully. Through internet banking, banking tasks which some people considered difficult to be understood, became easy for all clients. Clients who formerly found it difficult to understand a bank's instructions because they did not have enough time to go to the bank, now could learn and understand the instructions through internet banking which could be accessed any where and any time, which was really flexible for clients. Clear and easily understood instructions in internet banking caused clients to feel unhampered when they needed internet banking to perform their banking tasks. All the ease enjoyed by clients would automatically create positive attitude to use internet banking, which was a bank's method to help its clients in performing their banking tasks.

This result confirmed the result of the studies of Davis (1993), Chau \& Lai (2003), Kusuma \& Susilowati (2007), Medyawati et al. (2011), and Jahangir \& Begum (2008). Test results of this study showed that perceived ease of use had a positive and significant influence on attitude toward using internet banking. Clients believed that internet banking provided ease for them, among others ease to learn and understand bank's instructions. Thus, the ease of using internet banking motivated clients to use internet banking more often. 
The Influence of Perceived Usefulness on Attitude Toward using Internet Banking

Result of the hypotheses tests proposed that perceived usefulness had a positive and significant influence on attitude toward using. This was based on the test result which showed that clients believed that usage of internet banking would bring benefits for them, such as improvement in their work performance.

This implied that banks made the right decision in providing internet banking facilities. Internet banking as a physical representative of branch office gave many benefits to clients. Clients who formerly had to spare special time to come to the bank where they had to pass gradual procedures and queue up, now could finish their banking tasks more quickly, thus saving much time. Clients considered that their banking tasks now could be completed more quickly, and they could use their time to perform other tasks. This situation surely improved performance and productivity. All the benefits enjoyed by clients in using internet banking automatically would motivate clients to continue using internet banking. Clients' attitude in using internet banking raised from the need of a more personal system, so that when a system met the clients' need, they would automatically use that system.

The result of this study confirmed the empirical studies of previous researchers which stated that a person's positive attitude toward internet would urge the person to optimize the effectiveness or usage of internet (Widyarini, 2005). Clients' expected the benefits of internet banking in their work performance (Chau \& Lai, 2003). Other supported studies were the studies of Widyarini (2005), Davis (1993), and Yahyapour (2008). Thus, we could conclude that the result of this study proved that perceived usefulness variable had a positive and significant influence on attitude toward using variable.

\section{The Influence of Perceived Ease of Use on Actual Usage of Internet Banking}

The results of the hypotheses tests showed that perceived ease of use had a positive and significant influence on actual usage of internet banking, which supported the finding of Sathye (1999) which indicated that respondents who perceived that it was easy to use internet banking would become actual users of internet banking. Thus, the various ease enjoyed by clients had a positive influence on the usage of internet banking. Clients would no more judge and compare internet banking with other facilities provided by a bank, but they considered internet banking as the necessary means for making their bank transactions, and they would continuously use internet banking as the actual adoption of the new system.

This finding agreed with the findings of Davis (1989), Eriksson et al. (2005), Rigopoulos \& Askounis (2007), and Manzano et al. (2009). When a person considered that internet was easy to use, they would use it more often, or they would be more willing to use it (Yusoff et al., 2009). This study also proved that perceived ease of use variable had a positive and significant influence on actual usage.

\section{The Influence of Perceived Usefulness on Actual Usage of Internet Banking}

The results of the hypotheses tests showed that perceived usefulness had a positive and significant influence on actual usage of internet banking. When a person considered that a system was useful, then the person's usage of the system would raise (Yusoff et al., 2009). Thus, the benefits given by banks through internet banking would raise the adoption of this bank service. Clients enjoyed many benefits in using internet banking, so they would actually adopted of this service by continuously using it for their various banking transactions. Clients would also adopt internet banking service by repeated usage of this service, and by using this service for almost all their banking tasks. This proposition confirmed the findings of $\mathrm{Da}$ vis (1989) and Rigopoulos \& Askounis (2007), and clarified the influence of perceived usefulness variable on actual usage variable.

\section{The Influence of Attitude Toward Using on Actual Usage of Internet Banking}

Hypotheses tests results showed that attitude toward using had a positive and significant influence on actual usage of internet banking. This indicated that attitude toward using internet banking was influenced by the ease and benefits of this technology, which would bring a positive effect on the adoption of this service, which reflected a person's belief in internet banking and in the necessary usage of internet banking. Clients had a positive attitude which believed that internet banking was a facility which should be applied by all banks. Clients would feel like having a personal bank and being served personally. This finding confirmed the studies of Davis (1993) and Medyawati et al. (2011), and added the evidences of the influence of attitude toward using variable on actual usage variable. 


\section{CONCLUSIONS AND SUGGESTIONS}

When more financial institutions offer internet banking services, studies on the important factors which influence the acceptance or adoption of the technology become very crucial. An important issue of the study of information system is whether the determinants proposed in the study are significant in the decision of adopting the technology, which may differ from the factors observed by previous studies. Based on the theoretical Technology Acceptance Model, this study proposed and performed empirical examinations on 110 internet banking users in Denpasar.

The analysis results of the variables which influenced the adoption of internet banking services gave the following findings: perceived ease of use had a positive and significant influence on attitude toward using, perceived usefulness had a positive and significant influence on attitude toward using, perceived ease of use had a positive and significant influence on actual usage, perceived usefulness had a positive and significant influence on actual usage, and attitude toward using had a positive and significant influence on actual usage.

With the expansive growth of e-commerce applications including internet banking, the positive and significant results of this study indicated that further studies should be focused on adding variables and or indicators to the ones observed in this study, in order to enrich the model. Thus, the results of future studies would be better and the conclusions might be differrent from or similar to the conclusions of this study. If the conclusions are the same, it means that the model used in this study has a high consistency. It is advisable to know the precise number of the population of internet banking users so that the samples of the study represent the whole users of internet banking, which helps to obtain more accurate findings.

The results of the study should be validated in a larger context, in order to be of more benefits. This study was an effort to validate the findings of other studies in a different context by examining the adoption of internet banking services by users in Denpasar. Users from different cultures may show different interests in judging a technology.

\section{REFERENCES}

Anggraeni, N. M. S. \& Kerti-Yasa, N. N. 2012. Eservice Quality terhadap Kepuasan dan Loyalitas Pelanggan dalam Penggunaan Internet Banking. Jurnal Keuangan dan Perbankan, 16 (2): 329-343.

Chau, P. Y. K. \& Lai, V. S. K. 2003. An Empirical Investigation of the Determinants of User Ac- ceptance of Internet Banking. Journal of Organizational Computing and Electronic Commerce, 13(2): 123-145.

Cheung, C. S. 2001. Understanding Adoption and Continual Usage Behaviour towards Internet Banking Services in Hong Kong. Master Thesis. Hong Kong: Lingnan University.

Choi, J. Y., Kim, Y. B., Jun, Y. M., \& Kim, Y. H. 2011. A Bayesian Multivariate Probit Analysis of Korean Firms' Information System Adoption. Industrial Management \& Data Systems, 111(9): 1465-1480.

Davis, F. D. 1989. Perceived Usefulness, Perceived Easy of Use, and User Acceptance of Informatiom Technology. MIS Quarterly, 13(5): 319339.

1993. User Acceptance of Information Technology: System Characteristics, User Perceptions and Behavioral. International Journal Management Machine Studies, 38(3): 475-487.

Eriksson, K., Kerem, K., \& Nilsson, D. 2005. Customer Acceptance of Internet Banking in Estonia. International Journal of Bank Marketing, 23 (2): 200-216.

Ferdinand, A. 2002. Sctructural Equation Modeling dalam Penelitian Manajemen. Semarang: Badan Penerbit Universitas Diponegoro.

Gefen, D., Karahanna, E., \& Straub, D. W. 2003. Trust and TAM in Online Shopping: An Integrated Model. MIS Quarterly, 27(1): 51-90.

Giovanis, A. N., Binioris, S., \& Polychronopoulos, G. 2012. An Extension of TAM Model with IDT and Security/Privacy Risk in the Adoption of Internet Banking Services in Greece. EuroMed Journal of Business, 7(1): 24-53.

Islam, S. M. T. \& Chik, Z. 2011. Disaster in Bangladesh and Management with Advanced Information System. Disaster Prevention and Management, 20(5): 521-530.

Jahangir, N. \& Begum, N. 2008. The Role of Perceived Usefulness, Perceived Ease of Use, Security and Privacy, and Customer Attitude to Engender Customer Adaption in the Context of Electronic Banking. African Journal of Business Management, 2(1): 32-40.

Jaruwachirathanakul, B. \& Fink, D. 2005. Internet Banking Adoption Strategies for a Developing Country: The Case of Thailand. Internet Research, 15(3): 295-311.

Jun, M. J. \& Cai, S. H. 2001. The Key Determinants of Internet Banking Service Quality: A Content Analysis. The International Journal of Bank Marketing, 19(7): 276-294.

Juwaheer, T. D., Pudaruth, S., \& Ramdin, P. 2012. Factors Influencing the Adoption of Internet 
Banking: A Case Study of Commercial Banks in Mauritius. World Journal of Science, Technology and Sustainable Development, 9(3): 204 234.

Kaleem, A. \& Ahmad, S. 2008. Banker's Perception of Electronic Banking in Pakistan. Journal of Internet Banking and Commerce, 13(1): 1-16.

Kerem, K. 2003. Adoption of Electronis Banking: Underlying Consumer behaviour and Critical Success Factors. Case of Estonia. PRAXIS Center for Policy Studies.

Kesharwani, A. \& Bisht, S. 2012. The Impact of Trust and Perceived Risk on Internet Banking Adoption in India: An Extention of Technology Acceptance Model. International Journal of Bank Marketing, 30(4): 303-322.

Kusuma, H. \& Susilowati, D. 2007. Determinan Pengadopsian Layanan Internet Banking: Perspektif Konsumen Perbankan Daerah Istimewa Yogyakarta. Jurnal Akuntansi dan Auditing Indonesia, 11(2): 125-139.

Laukkanen, P., Sinkkonen, S., \& Laukkanen, T. 2008. Consumer Resistance to Internet Banking: Postponers, Opponents and Rejectors. International Journal of Bank Marketing, 26(6): 440-455.

Lech, P. 2012. Information Gathering During Enterprise System Selection: Insight from Practice. Industrial Management \& Data Systems, 112(6): 964-981.

Malhotra, N. K. 2006. Riset Pemasaran, Pendekatan Terapan. Jakarta: Indeks.

Manzano, J. A., Lassala-Navarre, C., Ruiz-Mafe, C., $\&$ Salva. 2009. Key Drivers of Internet Banking Services Use. Online Information Review, 22(4): 672-695.

Medyawati, H., Christyanti, M., \& Yunanto, M. 2011. E-Banking Adoption Analysis Using Technology Acceptance Model (TAM): Empirical Study of Bank Customers in Bekasi City. International Conference on Innovation, Management, and Service, 14(1): 91-95.

Mitic, M. \& Kapoulas, A. 2012. Understanding The Role of Social Media in Bank Marketing. Marketing Intelligence and Planning, 30(7): 668-686.
Ndubisi, N. O. \& Sinti, Q. 2006. Consumers Attitudes, system's Characteristics and Internet Banking Adoption in Malaysia. Management Research News, 29 (1/2): 16-27.

Rahardjo, B. 2001. Aspek Teknologi dan Keamanan dalam Internet Banking. Jakarta: PT Insan Indonesia.

Rigopoulos, G. \& Askounis, D. 2007. A TAM Framework to Evaluate User's Perception Toward Online Electronic Payments. Journal of Internet Banking and Commerce, 12(3): 1-5.

Sathye, M. 1999. Adoption of Internet Banking by Australian Consumers: An Empirical Investigation. Journal of Bank Marketing, 17(7): 324334.

Schiffman, L. \& Kanuk, L. L. 2008. Perilaku Konsumen. Jakarta: Indeks.

Sugiyono. 2008. Metode Penelitian Bisnis. Bandung: Alfabeta.

Walker, R H. \& Johnson, L. W. 2006. Why Consumer Use and Do Not Use Technology-Enabled. Journal of Service Marketing, 20(2): 125-135.

Widyarini, L. A. 2005. Analisis Niat Perilaku Menggunakan Internet Banking di Kalangan Pengguna Internet di Surabaya. Jurnal Widya Manajemen dan Akuntansi, 5(1): 101-123.

Yahyapour, N. 2008. Determining Factors Affecting Intention to Adopt Banking Recommender System, Case of Iran. Thesis. Sweden: Lulea University of Technology.

Yusoff, Y. M., Muhammad, Z., Pasah, E. S., \& Robert, E. 2009. Individual Differences, Perceived Ease of Use, and Perceived Usefulness in the E-Library Usage. Computer and Information Science, 2(1): 76-83.

Zhao, A. L. F., Hanmer-Lloyd, S., Ward, P., \& Goode, M. M. H. 2008. Perceived Risk and Chinese Consumers' Internet Banking Services Adoption. International Journal of Bank Marketing, 26(7): 505-525.

Zhao, A. L. F., Koenig-Lewis, N., Hanmer-Lloyd, S., $\&$ Ward, P. 2010. Adoption of Internet Banking Services in China: Is It All About Trust? International Journal of Bank Marketing, 28(1): 7-26. 